\title{
An Overview of Public History in Italy: No Longer A Field Without a Name
}

\section{Serge Noiret, European University Institute, Florence, Italy (serge.noiret@eui.eu)]}

\section{Introduction}

As in other countries, public history in Italy has developed in its own unique way. One of the country's most important nationwide industries, cultural tourism, is all about the Italian past and its heritage. The presence of the past in historical and archaeological heritage is ubiquitous in the country, from the cities to the smallest towns and villages. The very landscape is historical. Local communities locate their identity and memory in their historical heritage and for a very long time national cultural institutions have had deep connections with these communities.

Moreover, using the past in an instrumental way has very strong roots too, being embedded in cultural policies and in the foundation of the country's parliamentary republican party system, especially with regard to the memory of the Second World War, the Resistance, and the Civil War. Since the end of that war, there have been debates about who should control the past and the nation's historical memory. Local historical projects and the activities of cultural institutions shaped the way the country looked at its past - sometimes engaging with difficult memories - and through these developed a territorial and community-based approach to history.

Marcello Ravveduto, a historian of Italian organized crime, has defined public history as an archipelago $^{1}$ in which history in the public realm and in collaboration with the public is practiced across many separate islands. It can therefore be compared to digital humanities, often described by practitioners as a big tent or an umbrella field, which includes different sub-disciplines with digital history and digital public history being of primary concern to us. ${ }^{2}$

Given this background it is not surprising then that both individual historians and cultural institutions are open to the field of public history. Italians are amenable to importing concepts, approaches, and practices from other countries and adapting them to local traditions. Local institutions, archives, libraries, and museums have been prepared to adopt the term public history as a field which gives a name and a context to what they were already practicing and, in an

\footnotetext{
${ }^{1}$ Marcello Ravveduto, "Il viaggio della storia: dalla terra ferma all'arcipelago," Public History. Discussioni e pratiche, eds. Paolo Bertella Farnetti, Lorenzo Bertucelli and Alfonso Botti (Milano: Mimesis, 2017), 131-146, quote on 136. ${ }^{2}$ Serge Noiret, "Digital Public History" in A Companion to Public History, ed. David Dean (Hoboken: Wiley-Blackwell, 2018), 111-124; Enrica Salvatori, "Digital (Public) History: la nuova strada di una antica disciplina," RiMe. Rivista dell'Istituto di Storia dell'Europa Mediterranea 1/1n.s. (December 2017), http://www.rime.cnr.it/index.php/rime/article/view/8/7.
} 
interdisciplinary way and outside universities. In a general overview of public history in Italy, the way archival institutions, libraries, and, especially history museums, ${ }^{3}$ have engaged with public history in recent years is therefore an important part of the story. A very good example of how such initiatives are a feature of public history in Italy is the highly animated discussion generated about whether to create a museum of the history of Italy during the fascist era in Predappio, where Mussolini was born. ${ }^{4}$

Many Italian practitioners working within cultural institutions now feel that they had always been part of this field and this awareness was recently reinforced by the founding of the Italian Association of Public History (AIPH) in 2016. From this time on, Italians have engaged in fruitful discussions about the definition of the field itself, about the relationships between heritage studies, memory studies, museum studies, oral and digital history, popular history and about the ways in which history is communicated through different media and during commemorations.

\section{National paths for an international discipline}

Doing public history today in Italy does not only mean teaching or disseminating knowledge about historical issues being debated in the public arena and/or academic historians hoping to reach a wider audience; it also means working towards the goal of engaging with local communities in shaping identity, collective memory, and a sense of belonging. Such collaborations encourage critical engagement with issues such as what it means to be an Italian today within the contexts of migration, diversity, and globalization. This has created new opportunities for historians at a time when academic positions are increasingly scarce. Indeed, the introduction of the term public history in 2009 was in part a response to the wider crisis of humanities and history teaching at universities in Italy. Today, the field is recognized in the country as being part of new epistemological developments in the humanities, and the choice of the English term public history is motivated by a deliberate intention to refer to a growing international movement and to a relatively new field within the discipline of history, which has its origins in the late 1970s in the English-speaking world, particularly the United States. It also underlines the novelty of this professionalization in Italy, without the ambiguities that a literal translation in Italian (storia pubblica) might have created, as

\footnotetext{
${ }^{3}$ See Ilaria Porciani, "What can Public History do for Museums, What can Museums do for Public History?," Memoria e Ricerca 25, no. 1 (January-April 2017): 21-40, https:// doi: 10.14647/86341; on public history in museums see Serge Noiret, “A proposito di Public History internazionale e di uso e abuso della storia nei musei," Ibid, 3-20.

${ }^{4}$ See Serge Noiret, “A Museum of Fascism where Mussolini Is Born and Buried?" Public History Weekly 4, no. 32 (October, 2016): 32: dx.doi.org/10.1515/phw-2016-7178 and "Osservatorio Predappio. Per discutere del progetto di un museo sul fascismo," editorial, E-Review, rivista degli Istituti Storici dell'Emilia-Romagna in rete 6, (April 2018), https://e-review.it/osservatorio-predappio, 2018.
} 
this wording is close to the often-used phrase to describe the instrumentalization of history in the public sphere (abuso pubblico della storia).

In a country in which politicians do not hesitate to rewrite the past to support their own political cause, academic history is in a state of crisis. In 2019, historians and intellectuals reacted strongly against the government when it decided to remove the subject of history altogether from the maturità the high school final examination taken before entering the university. ${ }^{5}$ This reveals another important context for the emergence of public history in Italy besides the crisis within academianamely, new thinking about the role and future of history in Italian society, in a country whose citizens constantly question their national path and identity at every level.

The "Italian Public History Manifesto" of 2016, which will be discussed later in this article, argues that public historians must enter into public debates about history. They must address abuses of history, where the past is mystified or falsified to manipulate public opinion. The players here are both producers and consumers of history. They may represent a specific community aiming at fostering its own history in public or, on the contrary, and like memory fighters, popular storytellers or political actors, they may play with history in public and build their own vision of the past that necessitates a different history and collective memory in the present. Taking into consideration the social role of historians ${ }^{6}$ and social presence of the past in the public realm, ${ }^{7}$ Nicola Gallerano shaped for the first time the concept of uso pubblico della storia (usage of history) during a 1993 conference. Such a concept explained how the public use of history had different meanings depending on the various media used to communicate the past to the public, and on the various contexts and audiences of such dissemination. His argument, that different narratives competed for attention in the public sphere, was a significant landmark in the development of critical public history in Italy. ${ }^{8}$

\section{The forms and places of public history in Italy}

Given the pre-history of public history in Italy, it is important today, when developing an understanding of public history, to account for a range of impulses that have helped shape the field.

\footnotetext{
${ }^{5}$ See Andrea Giardina, Liliana Segre and Andrea Camilleri, "L'appello: la storia è un bene comune, salviamola," $L a$ Republica, April 2019, https://www.repubblica.it/robinson/2019/04/25/news/la storia_e un bene comune salviamola-224857998/ 6 Tommaso Detti, Lo storico come figura sociale, relazione inaugurale presso la Giunta Centrale per gli Studi Storici, L'organizzazione della ricerca storica in Italia (conference paper, Roma, December 16-17, 2014), http://www.gcss.it/wp-content/uploads/2015/09/Lo-storico-come-figura-sociale.pdf.

${ }^{7}$ Held in Rome and organized by the Istituto Romano per la Storia d'Italia dal Fascismo alla Resistenza [the Roman Institute for the History of Italy from Fascism to the Resistance].

${ }^{8}$ Nicola Gallerano, "Storia e uso pubblico della storia," in L'uso pubblico della storia, ed. Nicola Gallerano (Milano: Angeli, 1994). In the book, published after the conference, the labor historian Fernando Fasce described public history as a set of practices for doing history from below in the USA.
} 
Here we only have space to discuss a few of those impulses: public history centers in local communities, public history festivals, public archaeology, public history in academia, and applied public history.

Prominent in the $19^{\text {th }}$ century cultural landscape, local historical associations and institutions who served their publics and communities have continued to play a significant role in Italian public history. ${ }^{9}$ These include the Deputazione di Storia Patria (homeland history deputations), which publish books and primary sources as well as occasionally maintaining libraries and archives. Another national institution with local ramifications is the Istituto per la storia del Risorgimento italiano together with the Museo Centrale del Risorgimento in Rome (1911), one of the five Italian historical institutes whose mission is to promote the study of Italian history from the birth of the national state to the First World War and engage with local communities. Between 1947 and 1951, Italy's emergent political parties worked in close cooperation with the several new historical institutions that were created: the catholic Istituto Luigi Sturzo, the communist Fondazione Gramsci, the two Istituti della Resistenza (Resistance Institutes), and Milan's Istituto Nazionale per la Storia del Movimento di Liberazione in Italia (INSMLI, National Institute for the History of the Liberation Movement in Italy) - now the Parri Institute - which leads a network of over sixty historical institutes scattered throughout the national territory, interacting with universities and schools and carrying out many significant public history projects. ${ }^{10}$

The important presence of local festivals makes it evident that there is not one cultural center but rather a capillary network of decentralized regional, local, and urban communities, in which many territorial cultural institutions work on different historical periods. As academic historians began to engage with popular forms of historical production written by non-historians - such as novels - history festivals provided a venue where they could reach large audiences and capture attention through their storytelling. Participating in festivals reaffirmed the social role of historians who often created new forms of history narratives for different audiences while maintaining a high academic standard. As Elisabetta Vezzosi noted in 2009:

The success of festivals and public lectures has prompted new questions on the sense of history and the academic profession, on the desires of the public and on the forms of its reception.... As historians, we all do research, analyze and interpret our sources, and communicate the results. If

\footnotetext{
${ }^{9}$ Ilaria Porciani and Mauro Moretti, "Italy" in Atlas of European historiography: the making of a profession 1800-2005 eds. Ilaria Porciani and Lutz Raphael (Basingstoke: Palgrave Macmillan, 2010), 115-122.

${ }^{10}$ Ultime lettere di condannati a morte e di deportati della Resistenza italiana; Atlante delle Stragi Naziste e Fasciste in Italia.
} 
the primary difference between public and academic history is the type of communication we try to develop, the type of audience we try to reach, and the type of products we try to convey, then the history festivals and their successes have helped to create more historical sensitivity, new ways of feeling, and innovation in discursive practices. ${ }^{11}$

Through public lectures at these festivals, academic historians not only engage with publics but they can help shape public discourse about the past. ${ }^{12}$ In some cases, there are interactive elements: each year since 2001, on the $10^{\text {th }}$ of August, a public trial is organized in Romagna, in which the public interacts with the proceedings of trial itself. ${ }^{13}$ The newest addition is the publisher Laterza's Lezioni di Storia Festival, the first Southern Italian festival, which took place in Naples in April 2019. In addition to these popular encounters with historians, some Neapolitan historic monuments can be interpreted using a downloadable, free digital App. ${ }^{14}$

Italian public festivals are one of the most popular sites of Italian public history, involving the communication of history to a wider public by academic historians outside the boundaries of universities. Francesco Catastini, who has organized cultural and public history shows in Italy, writes that "history festivals represent a place [...] where you can encounter consolidated experiences of spectacularizing history, namely theater, music, cinema, and historians with the public." ${ }^{\prime 15}$ He thinks that Italian festivals represent a show with much more content than just highlevel academic lessons for a large audience of participants in public squares or theaters: it is about building a complex public history event for the public.

Italy is a country where the past also belongs to the local communities that think cultural heritage must be enhanced, sustained, and narrated publicly. In the absence of adequate public funds and sufficient staffing, and despite UNESCO's declaration that Italy is the leading country in terms of its 54 recognized sites of important cultural heritage, the enhancement of Italy's magnificent pasts (Etruscans, Romans, medieval cities, renaissance heritage, etc.) often depends on the work of unpaid volunteers. ${ }^{16}$ It is not surprising then that the term public archaeology, coined by Chiara Bonacchi

\footnotetext{
${ }^{11}$ Elisabetta Vezzosi, ed. "I festival di storia e il loro pubblico. Interventi di Michael Frisch, Marco De Nicolò, Giuseppe Laterza, Adriano Ossola, Angelo d'Orsi," Contemporanea, Rivista di storia dell'800 e del '900, no. 4 (2009): 717-742, quote on pp. 718-719.

${ }^{12}$ Beatrice Borghi, 'La 'Festa della Storia': un progetto di public history [The Festival of History: a project of public history], Her \& Mus - Heritage \& Museography, no. 14 (June-July 2014): 21-28, https://www.raco.cat/index.php/Hermus/article/view/313319/403447.

${ }^{13}$ Summaries of all previous editions here http://www.sammauroindustria.com/it/eventi/processo-X-agosto

${ }^{14}$ Lezioni di Storia Festival: il passato è presente (Napoli, April 25-28, 2019), https://www.lezionidistoriafestival.it/

${ }^{15}$ Francesco Catastini, "I festival di storia, una via italiana alla Public History," Memoria e Ricerca, no. 37 (May-August 2011): 143-154, quoted on 147.

${ }^{16}$ UNESCO, Properties inscribed on the World Heritage List in Italy; Mauro Agnoletti, ed., Italian Historical Rural Landscapes: Cultural Values for the Environment and Rural Development, (Dordrecht: Springer, 2013).
} 
in 2009, gained currency in Italy before public history. ${ }^{17}$ Public archaeologists engage local communities through fieldwork, and they foster a common public awareness of the value of local heritage by promoting activities and including re-enactments, which are popular public history practices. $^{18}$

In addition to these forms of public history, notice must also be taken of the growing importance of the field within the realm of academic journals. In 2009, Luigi Tomassini and Francesco Mineccia curated a special monographic issue of the journal Ricerche Storiche, which was entirely dedicated to Media and History. Public archaeology and public history were tackled in two different essays. For the first time in Italy public history was mentioned in the title of an academic essay. ${ }^{19}$ Two years later the first mention of the words public history appeared in the title of a special issue of Memoria e Ricerca - Public History, National Practices and Global Identity. ${ }^{20}$ In that same 2011 journal, in an essay dealing with 3D reconstruction of the D-Day battle in Normandy, the concept of digital public history was used for the first time in Italy. ${ }^{21}$

As well as academic journals, public history began to be the focus of academic conferences, stimulated by debates about history and memory, often dubbed the memory wars, especially around commemorations. In 2013, Marcello Ravveduto commented that

Memory is the privileged field of action of Public History [...]. The memory of the victims of the mafias, of terrorism, of the Shoah, of the foibe (sinkholes), of natural disasters, at work and on duty, has given rise to a "geography of memory" founded on renewed "identity infrastructures": historical parks, museum organizations, holidays, civil rituals, institutional ceremonies, place names etc. An Italian Public History should set itself the goal of rebalancing the relationship between history and memory, examining the memory of the past with critical methods. ${ }^{22}$

\footnotetext{
${ }^{17}$ Chiara Bonacchi, “Archeologia pubblica in Italia: origini e prospettive di un 'nuovo' settore disciplinare," Ricerche storiche 39, no. 2-3 (May-December 2009): 329-350; Francesco Ripanti, "Italian public archaeology on fieldwork: an overview," Archeostorie, Journal of Public Archaeology, https://doi.org/10.23821/2017_4a; Guido Vannini, Archeologia Pubblica in Toscana (Firenze: University Press, 2011).

${ }^{18}$ Enrica Salvatori, "Il public historian e il revival: quale ruolo?," in Rievocare il passato: memoria culturale e identità territoriali, eds. Francesco Dei and Claudio Di Pasquale (Pisa: Pisa University Press, 2017), 131-138.

${ }^{19}$ Chiara Bonacchi, "Archeologia pubblica in Italia: origini e prospettive di un 'nuovo' settore disciplinare," Media e storia 39, no. 2-3 (May-December 2009): 329-350; Serge Noiret, "Public History" e "storia pubblica" nella rete," Ibid., 275-327.

${ }^{20}$ Serge Noiret, ed., Public History. Pratiche nazionali e identità globale, (Public History: national practices and global identity) Memoria e Ricerca, no. 37 (May-August 2011).

http://www.fondazionecasadioriani.it/modules.php?name=MR\&op=showfascicolo\&id=54.

${ }^{21}$ Marie-Pierre Besnard, "Notre-Dame de Saint-Lô in the English Channel: a 3D solution after the destruction during WWII," Memoria e Ricerca, no. 37 (2011): 193-212, http://www.fondazionecasadioriani.it/modules.php?name=MR\&op=body\&id=558

${ }^{22}$ Marcello Ravveduto, "Una Italian Public History per la seconda Repubblica," Officina della Storia, no. 10 (December 2013), https://www.officinadellastoria.eu/it/2013/12/27/una-italian-public-history-per-la-seconda-repubblica/.
} 
The very first Italian conference dedicated entirely to public history, Public History: a new way of approaching history, was held in 2014, organized by the Ottoman historian Maria Pia Pedani. ${ }^{23}$

A fundamental step in developing public history in Italy was the launch of the first public history master at the University of Modena and Reggio Emilia in 2015. ${ }^{24}$ The directors of the program, Lorenzo Bertucelli and Paolo Bertella Farnetti, also edited the first Italian book discussing public history methods, goals, and specific practices, with each chapter written by a different author, many of whom collaborate on the master's degree program. If we include the monographic essay in Memorie e Ricerche in 2011, these collected essays remain the most consistent and sophisticated reflection that Italy has produced on public history up to now. ${ }^{25}$

Besides discussions about public history and memory, a fruitful debate has taken place in Italy - at conferences and on the pages of journals - about the relationship between public history and academic history or, to put it another way, between public historians and academic historians. ${ }^{26}$ This has included a lively discussion over whether the term applied history would be better suited to the Italian context than public history. ${ }^{27}$ This has opened up new possibilities such as reflections on new historiographies of historical practice like microhistory, history from below, and oral history. ${ }^{28}$ Bertucelli has reflected at length on many of these issues:

In order to root public history in Italy, it is useful to clarify how public history shares a methodological approach based on the awareness that history (the whole history) is a

23 Public History. Un nuovo modo di avvicinarsi alla storia, (Venice, April 10, 2014), See https://dph.hypotheses.org/345; Maria Pia Pedani, "Uso Pubblico della Storia. Connessioni Veneziani," Giornale di Storia, no. 17 (2015):

https://www.giornaledistoria.net/monografica/uso-pubblico-della-storia-monografica/maria-pia-pedani-connessioniveneziane/

${ }^{24}$ Unimore: Master in Public History

${ }_{25}$ Lorenzo Bertucelli, "La Public History in Italia. Metodologie, pratiche, obiettivi," Public History. Discussioni e pratiche, no. 34 (2017): 75-96.

${ }^{26}$ Angelo Torre, "Public History e Patrimoine: due casi di storia applicata," Quaderni storici, Rivista quadrimestrale, no. 3 (December 2015): 629-660.

${ }^{27}$ See Lorenzo Bertucelli, "La Public History in Italia. Metodologie, pratiche, obiettivi," Public History. Discussioni e pratiche, no. 34 (2017): 75-96, quoted on 83-84. See also Benedetta Giuliani, "Dalla public history alla applied history. Ruolo pubblico e funzione politica della storia nel recente dibattito storiografico angloamericano," Diacronie. Studi di Storia Contemporanea 32, no 4 (2017): 14-15, http://www.studistorici.com/wpcontent/uploads/2017/12/01_GIULIANI.pdf.

${ }^{28}$ Key works include Carlo Ginzburg, Il formaggio e $i$ vermi: il cosmo di un mugnaio del '500 [The cheese and the worms: the cosmos of a sixteenth-century miller] (Torino: Einaudi, 1976); Giovanni Levi, L'eredità materiale: carriera di un esorcista nel Piemonte del Seicento (Torino: Einaudi, 1985); Luisa Passerini, Fascism in Popular Memory: The Cultural Experience of the Turin Working Class (Cambridge: Cambridge University Press, 2009); Luisa Passerini, Autobiography of a Generation: Italy, 1968 (Hanover, NH: University Press of New England, 1996); Alessandro Portelli, Biografia di una Città: Storia e Racconto: Terni 1830-1985 (Turin: Einaudi, 1985); Alessandro Portelli, The Death of Luigi Trastulli and Other Stories: Form and Meaning in Oral History (Albany: State University of New York Press, 1991); Alessandro Portelli, They Say in Harlan County: An Oral History (New York: Oxford University Press, 2011). 
“cultural construction." It is particularly important for those who - like public historians focus on the sharing of the making of history, the cooperation and the involvement of the public in the critical analysis of sources and of its interpretative process. [...] A historiographic reconstruction does not deny its rhetorical dimension, its being a "story," even a storytelling, but it sustains how evident [...] is its founding and legitimizing nucleus, an irreplaceable pillar of truth. Thus, finding sources, constructing arguments based on evidence, and disseminating knowledge are the stages of the interpretative path of the historian, a path that a public historian intends to follow together with his public, a way to tell "the whole story," precisely also the toolbox that has to be shared with the public and which shows how "history is built." 29

Bertucelli's essay was the first attempt - together with other authors' contributions in the book - to offer a historiographical contribution to the history of public history in Italy. Another essay shaping the Italian way to public history was recently written by Mirco Carrattieri, who graduated from the master's program in public history in Modena. ${ }^{30}$

\section{Conclusion: the foundation of AIPH and the "Italian Public History Manifesto"}

The idea to create an Italian national association of Public History (AIPH) ${ }^{31}$ emerged in 2015, in Jinan, China, during the International Committee of Historical Sciences conference that also hosted the International Federation for Public History's second annual conference. The first AIPH constituent meeting was held in Rome in 2016, drawing together representatives from eighteen historical and professional associations. ${ }^{32}$

Feeling the need for a reflection on best practices of public history, the AIPH decided to write an "Italian Public History Manifesto," inspired by international examples. ${ }^{33}$ It begins by saying that while the past is everywhere, historians who make sense of that past are often absent from public discourses about it. ${ }^{34}$ In offering a comprehensive discussion concerning the question "What is Public History?" and by sharing perspectives on the way public history functions in Italy, the "Italian Manifesto" not only engages with the Italian-ness of Italian public history but also contributes to discussions that have been taking place globally.

\footnotetext{
${ }^{29}$ Bertucelli, "La Public History in Italia," 84-86.

${ }^{30}$ Mirco Carrattieri, "Per una public history italiana," Italia Contemporanea, no. 289, (April 2019): 106-121.

${ }^{31} \mathrm{https}: / /$ www.aiph.it

${ }^{32}$ For these early steps see Agostino Bistarelli, "Il vantaggio dell' arretratezza? Innovazione e tradizione nella via italiana alla public history," Italia Contemporanea, no. 289, (April 2019): 97-105.

${ }^{33}$ David Armitage and Jo Guldi, Manifesto per la storia. Il ruolo del passato nel mondo d'oggi, trans. David Scaffei (Roma: Donzelli, 2016).

${ }^{34} \mathrm{https}: / /$ aiph.hypotheses.org/5442
} 
Through drawing up the "Italian Public History Manifesto," the AIPH is striving to ensure that the results and the methodologies of historiographical research are known to a wider public, that history is communicated well and with greater emotional involvement by various publics. Sound community research through collaboration with the public will lead to newer, more popular, and more original developments in presenting historical knowledge. For Italian public historians, it becomes essential to consider publics, whether specialized or not, both as privileged interlocutors and as potential protagonists of history-making. In this way, public history will contribute to the restoration - both to history and to historians (outside and inside universities) - of a central role in interpreting the complexities of contemporary Italian society in which collective memories populate long-term historical explanations. 